\title{
Lapurdum
}

LAPURDUM Euskal ikerketen aldizkaria | Revue d'études basques |

Revista de estudios vascos | Basque studies review

$5 \mid 2000$

Numéro V

\section{Asko ren zenbait alderdi}

\section{Ricardo Etxepare}

URL : http://journals.openedition.org/lapurdum/1290

DOI : 10.4000/lapurdum.1290

ISSN : 1965-0655

Éditeur

IKER

Édition imprimée

Date de publication : 1 octobre 2000

Pagination : 99-111

ISBN : 2-84127-161-7

ISSN : $1273-3830$

\section{Référence électronique}

Ricardo Etxepare, «Asko ren zenbait alderdi », Lapurdum [Linean], 5 | 2000, Sarean emana----an 01 juin 2009, kontsultatu 03 juillet 2020. URL : http://journals.openedition.org/lapurdum/1290 ; DOI : https:// doi.org/10.4000/lapurdum. 1290 


\title{
Asko ren zenbait alderdi
}

\author{
Ricardo Etxepare
}

UMR 5478

\section{Sarrera}

Euskararen zenbatzaile batzuk (asko, gutxi, hainbat, zenbait, ugari, franko, gehiago/gutxiago) hirugarren pertsona singularreko komunztadura hartzen ahal dute, beren interpretazio plurala gora-behera:

(1) a. Bezero asko sartu da gaur b. Bezero asko sartu dira gaur

Euskararen gramatika tradizional eta deskriptiboek (aipatu izan dutenean) bi eratan hartu izan dute fenomeno hau²: batzuek (Lafitte, 1962, 111.orr.; Euskaltzaindiaren Euskal Gramatika Laburra:Perpaus Bakuna, 1993, 105109.orr.), guziz hautazkotzat bezala jotzen dute ; besteek, berriz, (Txillardegi, 1979 ; Euskaltzaindiaren EGLU I, 1985, 205-208.orr.), zenbatzailearen ondoan dagoen izenaren izaera nozional (masa/objektu) edo algebraikoaren (multzo/banako) markatzaile gisa hartzen dute komunztaduraren agertzea edo ezabatzea. Lan honek asko zenbatzailearen eta komunztaduraren arteko elkarketaren analisi xeheagoa egin nahi luke, orain arte kontutan hartu izan den datu eremua zabalduaz, eta tartean diren nozio semantikoak argituaz ${ }^{3}$. Erakusten saiatuko gara zenbatzaile plural komunztaduragabeak ((1a) erakoak) distributiboak eta proportzionalak direla.

Lehen atalean, fenomeno honetaz agertu diren iritzien azterketa kritikoa egingo dugu. Bigarrenean, komunztaduragabeko zenbatzaile pluralen propietate distributiboak agertuko ditugu: ahalbideratzen dituzten uztardura erlazioen eremu hertsia (2.1), zenbatzaileen multzo izaerari dagozkion desberdintasunak (2.2.), predikazio klase desberdinen aurreko portaera diferentea (2.3.) eta azkenik, banaketa adierazten duten beste osagaiekin (elkarkariak eta -na atzizkidun sintagmak) konbinatzeko ezintasuna (2.4), (2.5). Hirugarren atalean, komunztadurarik gabeko asko-ren propietate proportzionala aztertuko dugu. Eztabaida osoa maila deskriptiboan egina da.

\section{Orain artekoak: Txillardegi (1978) eta EGLU I (1985)}

Zenbatzaileen eta komunztaduraren arteko erlazioaz idatzi diren lan asko Txillardegirenean dute iturburua $(1972,1977,1978)$. Txillardegiren arabera $(1978$, 
37. eta 62-63.orr.), komunztaduragabeko zenbatzaileek (kardinaletatik hasita) multzotasuna adierazten dute, eta komunztaduradunek berriz, multzoaren elementuak, banaka hartuta ${ }^{4}$. Txillardegiren ustea mugagabetasunaren ikuspegi jakin baten baitan ulertu behar da. Haren arabera, pluraleko forma guztiak bi eratan eman daitezke : (i) multzo gisa ; (ii) multzo horren barneko elementuen zenbaketa gisa. Lehenbizikoari mugagabea dagokio ; bigarrenari berriz artikulu plurala eta pluraleko komunztadura. Pluraleko forma desberdinen arteko aurkakotasuna perpaus pare honen bitartez eman daiteke (37.orr.) :

(2) a. Hiruri aditzen zaio

b. Hiruei aditzen zaie

Lehenbizikoak hiru kantarik osatutako multzoa adieraziko luke, eta bigarrenak hiru kantari desberdinen jarduna, nor bere aldetikakoa. Ikuspegi honen baitan, (3b) bezalako perpausak, (3a)ren ordezkotzat hartuak, sistematik kanpo gelditzen dira, eta Txillardegik erdaratikakotzat jotzen ditu :s

\section{(3) a. Bi liburu erosi dut $\quad$ b. Bi liburu erosi ditut}

Sistema berbera kardinalak ez diren zenbatzaileetara ere zabaltzen du. Honela, asko mugagabe komunztaduragabea multzotasunaren adierazle ateratzen da, eta asko komunztaduraduna, berriz, askotasuna osatzen duten elementuen adierazle ${ }^{6}$ Tarteko exenpluak, hala nola (1b)ren gisakoak, sistemaz kanpokoak dira, eta erdarari egotzi behar zaizkio. Txillardegiren sisteman, ez da deus ere esplikatu beharrik (la) eta (1b) bezalako fenomeno baten aurrean, (1b) « kutsaturiko» forma bat baita, euskal sistema zaharrari iratxeki zaiona kanpo eragileen bitartez. Txillardegiren mugagabetasunaren ikuspegiaz zenbait jende mintzatu da lehenago, zuzen osoz arbuiatzeko ${ }^{7}$. Deskriptiboki, Txillardegik zubereraren ekarrietan hartzen du oin ${ }^{8}$. Egungo zubereraren arauak, baina, askoz ere konplikatuagoa ematen du (Coyos, 1999) $)^{\circ}$, eta ez du biderik ematen Txillardegik proposaturiko arau (deskriptibo) horretarako.

EGLU I -ek (1985, 223.orr.) masa/banako oposizioaren baitan ezartzen du numero komunztaduraren ezabatzea ${ }^{10}$. Adibide gisa honako bi perpauson konparazioa ematen du:

(4) a. Liburu asko erosi dut

b. Liburu asko erosi ditut

(4a)k eta (4b)k, EGLU I-en arabera, ez dute interpretazio bera: « ...lehenbiziko adibidean liburu 'masa' hartzen dugu gogoan. Bigarrenean, berriz, liburu bat, eta beste bat e.a. » Berehala, argiagoa izan nahi duen exenplu batera jotzen du, oraingoan « harri asko » bezalako izen sintagma batekin :

\section{(5) a. Harri asko bota dute b. Harri asko bota dituzte}

(5a)n, « harri » zenbakaitz modura hartua da, harri kantitate handi baten gisa. Aldiz, (5b)n, harri kopuru haundia (harri ale asko, alegia) bota dutela esaten da. Ezer baino lehen, ohar gaitezen honek zuzenean konponduko lukeela komunztaduraren auzia: masa izenek ere ez dute ageriko komunztadurarik.

EGLUren hipotesiak badu problema handi bat: harria masa izan daiteke, ura, ardoa edo ogia bezala. Liburua, ordea -ibaia, zirkulua edo molekula bezala-, ez ${ }^{1 \mathrm{t}}$. 
Masa bezala hartua izateak baditu ondorio gramatikal garbi batzuk, « liburu » hitzak onartzen ez dituenak. Hona hemen bost : (i) « harri »-k neurtua izatea ahalbidetzen du, baina « liburu »-k ez :

(6) a. Hiru kilo harri

b. \#Hiru kilo liburu

(ii) Artikulua hartzen duelarik, " harri » bezalako hitz bat (« ogia », « ardoa » edo " ura " masa hitzak bezala) ez da nahitaez entzule/hizlariaren ezagun bihurtzen. «Liburu » bezalako izen zenbagarri bat berriz bai (« aulki », « mahai », edo «bizilagun » bezala) :

(7) a. Harria ekarri dute (zuk espero zenuena, edo lehen aipamena diskurtsuan) b. Liburua ekarri dute (zuk dakizun hori, nahitaez)

(iii) Lonning-ek (1987) ikusi zuen bezala, masa terminoek ezin dute predikazio erlazioan egon " homogenotasunaren $»^{12}$ propietatea erakusten ez duten predikatuekin. Izen zenbagarriak bai :

(8) a. *Ur askok 3 kilo baino gehiago pisatzen du

b. Zaldi askok 300 kilo baino gehiago pisatzen du

(iv) Masa izenez osaturiko sintagma kuantifikazionalak predikatu gisa ager daitezke, ez ordea izen zenbagarriz osaturikoak :

(9) a. Eraztun hori urre asko da b. Zaku hori harri asko da

(10) *Multzo/talde hori ikasle asko da

(v) Azkenik, ikusi dugu singularreko komunztadura asko ren propietatea bakarrik ez dela: bada zenbatzaile multzo bat propietate berbera erakusten duena. Horietako batzuk ez dute masa izenik onartzen, zenbait -ek edo hainbat -ek, $\mathrm{kasu}^{13}$.

(11) a. \#Zenbait ardo edan dugu (masa interpretazioan)

b. \#Hainbat ardo edan dugu (masa interpretazioan)

Fenomeno berberaren aurrean bagaude, pluraleko komunztaduraren ezabaketak ezin du lotua egon izenaren masa izatearekin.

Hurrengo ataletan, asko +izen zenbagarri+singularreko komunztadura egituren semantikazko puntu batzuk argitzen saiatuko naiz. Horretarako sintaxi eremua zabalduko dut, egitura horiek kontestu sintaktiko desberdinetan paratuaz eta haien portaera aztertuaz.

\section{Singularreko formen izaera distributiboa}

\subsection{UZTARDURAREN EREMUA}

Hizkuntza naturalek erreferentzia kidetasuna adierazteko elementu berezituak: dituzte, anafora izena dutenak: anaforak, aurretik mugaturiko erreferentzia jakin baten berritzaile dira. Erreferentzia hori, hizketa kontestuak nahiz perpausean gauzaturiko izen sintagmek ekartzen dute. Perpausean gauzaturiko erreferentzia ekar- 
leak izendatzeko aitzindari hitza erabiltzen da. Aitzindariaren eta anaforaren artean ezartzen den erlazioari uztardura deituko diot (Salaburu,1985). Gauza jakina da, Postal (1971) eta Reinhart-en (1983) lanaren ondorioz bereziki, aitzindariaren izaera semantikoak zer esan haundia duela aitzindariaren eta anaforaren artean uztardura erlazioa ezarri ahal izateko orduan. Ikus esate baterako bi perpauson arteko diferentzia :

(11) a. Langile hori, baitezpadakoa zaigu, baina /berak beste lantegi batera joan nahi du.

b. * Langile bakoitza/mundu guztia ${ }_{i}$ baitezpadakoa zaigu, baina_/berak beste nonbaitera joan nahi du.

(11a) exenpluan baitezpadako langilea eta beste nonbaitera joan nahi duena langile berbera izan daitezke (berez, kontestu honetan nekez uler daiteke bestela). (11b)n ordea, ezin uler daiteke horrela: langilea eta beste lantegira joailea diferenteak izan behar dute erreferentzian, nahi eta nahi ez (hortik sortzen da perpausen arteko non sequitur efektua). Arazoa ez da berez langile bakoitza sintagma. Honelako sintagmak aitzindari izan daitezke bestela ere :

(12) Langile bakoitzak/mundu guztiaki pentsatzen $\mathrm{du}_{\neg}$ beste lantegi batera joan beharko duela

(11) eta (12) exenpluetatik sortzen den generalizazioa hauxe da : izen sintagma erreferentziadunak ez bezala, erreferentzia zuzena ez duten elementuek perpaus beraren barnean bakarrik joka dezaketela aitzindari gisa. Zenbatzaileon ezintasunak ez dira hor bukatzen : har esate baterako ondoko bi perpausok.

(13) a. [Bizilagun bakoitzak]; [_/berai agurtzen duen auzotarra] gorrotatzen du b. *[_/bera agurtzen duen bizilagunak] [auzotar bakoitza] i gorrotatzen du

Postalek (1971) ikusi zuen bezala, aitzindaria honelako zenbatzaile bat denean, aitzindaria eta anaforaren artean uztardura erlazioa ezartzeko kondizio sintaktiko bat obeditu behar da: (informalki mintzatuaz) aitzindariak ezin du egon, sintaxi egituran, anafora baino azpirago (ikus baita ere Zribi-Hertz 1996, 87-96.orr). Kondizio hori (13a)n obeditzen da, ez ordea (13b)n. Kondizio hau zenbatzaileei bakarrik dagokie. Ikus bestela (14) :

(14) a. [Gure bizilagunak $]_{i}\left[\right.$ /bera $a_{i}$ agurtzen duen auzotarra] gorrotatzen du

b. [ $\__{i}$ agurtzen duen auzotarrak] gure bizilaguna ${ }_{i}$ gorrotatzen $\mathrm{du}$

(14) exenpluan ez bezala, (12) eta (13)an anaforaren erreferentzia zenbatzailearen hedaduraren arabera aldatzen da. Beste hitzetan esanda, anafora hor aldagai bat da.

Asko ren kasura itzulita, ohartzen gara komunztaduradun eta komunztaduragabeko aldaerek ez dutela berdin jokatzen uztardurari buruz: komunztaduradun aldaerek erreferentziadun sintagmek bezala jokatzen dute ; komunztadurarik gabeek ordea, zenbatzaileek bezala. Hasteko, uztardura ezin ezar daiteke perpausetik kanpo singularreko komunztadura gordeaz, bai ordea pluralekoarekin :

(15) a. * Bezero asko ez da aspaldian agertzen, baina ezin diogu ${ }_{\rightarrow}$ etxera deitu b. Bezero asko ez dira aspaldian agertzen, baina ezin diegu ${ }_{i}$ etxera deitu 
Ikusi gainera, hau ez dela gertatzen masa izenez hornituak datozen izen sintagma singularrekin :

(16) a. *Bezero asko sartu da gaur. Ez da halabaina ${ }_{i}$ oso pozik atera. b. Harri asko ekarri dute gaur. Ez da, halabaina, „ ${ }_{i}$ nahi genuen modukoa.

Bakoitz -en moduko zenbatzaileekin gertatzen den bezala, aitzindariaren posizio sintaktikoak ere axola du :

(17) a. Bezero askok [ $_{-i}$ genero txarra saltzen dien dendaria] salatzen dute b. [ ${ }_{-i}$ genero txarra saltzen dien dendariak] bezero asko $_{i}$ aspertzen ditu

(18) a. Bezero askok ${ }_{i}{ }_{-i}$ genero txarra saltzen dion dendaria] salatzen du b. [_* ${ }_{i j}$ genero txarra saltzen dion dendariak] bezero asko aspertzen du

Anaforaren eremuan, bada oraindik beste ezaugarri bat komunztadurarik gabeko zenbatzaileak bereizten dituena, komunztadura egiten dutenei buruz. Gogora komunztadurarik egiten duten nahiz egiten ez duten zenbatzaileek pluraleko anafora ukan dezaketela :

(19) a. Bezero asko sartu da gaur. Ez dira, halabaina, ${ }_{i}$ oso pozik atera. b. Bezero asko, sartu dira gaur. Ez dira, halabaina, ${ }_{-i}$ oso pozik atera

Aldiz, kontestu sintaktiko jakin batzuetan komunztadurarik gabeko zenbatzaileak singularreko formadun anafora baizik ez dezake baimen:

(20) a. Bezero askok ${ }_{\mathrm{i}}\left[{ }_{-i}\right.$ beherapen bat egingo diozula/*diezula] uste du b. Bezero askok $\left[{ }_{i}\right.$ beherapen bat egingo * diozula/diezula $]$ uste dute

(21) [Eskolatik $\rightarrow$ botatzen badute] ikasle askok (oraindik ere) beste eskola batean sartzeko eskubidea izanen $\underline{\mathrm{du} / *}$ dute

Honetan ere, komunztadurarik gabeko asko bakoitz -en moduko zenbatzaileen gisan portatzen da :

(22) Bezero bakoitzak/mundu guziak ${ }_{-}$, beherapen bat egingo diozula/*diezula] uste du

Ezaugarri horiek erakusten dituzten zenbatzaileak zenbatasun moeta jakin bati dagozkio: banaketari, alegia. Uztardura datuez aparte, honek komunztadurarenak ere argitzen ditu : komunztadura eza ez da bakarrik masa elementuen propietate bat, baizik eta zenbatzaile distributiboak biltzen dituen ezaugarri morfologikoa ere bai ${ }^{14}$.

\subsection{IrAKURKETA KOLEKTIBO ETA DISTRIBUTIBOAK}

Har dezagun ondoko perpausa:

(23) Gazteek harritzar hori altxatu dute

Perpausak bi interpretazio ukan ditzake: gazteek, elkar hartuta, harritzarra altxatu dute, edo taldeko gazte bakoitzak egin du, zaharragoei haizu ez zaigun erakustaldi bikainean. Lehenbiziko interpretazioari interpretazio kolektiboa deituko diot. Bigarrenari interpretazio distributiboa. Asko -ren kasuan, badirudi komunz- 
taduraren presentziak eragina duela sortzen diren interpretazioetan. Horra lehenbizi komunztaduraduna :

(24) Azkenean gazte askok altxatu behar izan zuten harritzarra

(24)k baditu bi interpretazio, (23)k bezala : interpretazio kolektiboa, non gazteek elkarrekin altxatu behar izan zuten harritzarra, eta interpretazio distributiboa, non gazteek bakarka altxatu zuten eta halaxe egin zutenak asko ziren.

Orain komunztaduragabea :

(25) Azkenean gazte askok altxatu behar izan zuen harria

(25) perpausak interpretazio bakarra du: distributiboa. Ezin uler daiteke, (25) esanik, gazteek harritzarra elkarrekin altxatu zutela, bakarka izan behar du ${ }^{15}$.

Singularreko formak distributiboak badira, espero dugu banakako interpretazioa onartzen ez duten predikatuekin ez direla ongi joango. Predikzioa, itxura batean, betetzen da :

(26) a. Ikasle ohi asko(k) festa horretan topo egin zuten/topatu ziren

b. ${ }^{*}$ Ikasle ohi asko(k) festa horretan topo egin zuen/topatu zen ${ }^{16}$

(27) a. Lantegian, langile asko batzartu ziren

b. *Lantegian, langile asko batzartu zen

\subsection{Predikazio kategorikoak eta egoerazkoak}

Asko singularrekoa ezin du agertu predikazio kategorikoetan (subjektuaren berezko propietate bat nabarmentzen duten predikazioetan, alegia -Kuroda, 1972 ; Carlson, 1980 ; Kratzer, 1988, besteak beste) :

(28) a. Ikasle asko altuak/azkarrak/argiak dira

b. *Ikasle asko altua/azkarra/argia da

Egoera bati buruzko predikazioetan arazorik ez dago:

(29) a. Ikasle asko gaisorik dago egunotan

b. Ikasle asko gaisorik daude egunotan

Antzeko zailtasunak sortzen dira bakoitz - ekin :

(30) a. ?? Ikasle bakoitza argia da

b. Aulki bakoitza hautsita zegoen

Bakoitz -ek hala ere badu nolabaiteko askatasuna, partitiboki jokatzen bada :

(31) a. Bertako ikasle bakoitza argia da

b. Talde horretako jokalari bakoitza indartsua da

Posibilitate hau ez dago komunztaduragabeko asko -ren esku. Komunztaduragabeko formek ez dezakete egitura partitiborik har:

(32) a. Ikasle asko etorri da

b. *Ikasle ohietako asko etorri da 
Iduri du predikazio kategoriko bat egiteko, izen sintagmaren erreferentzia ondo definitua egon behar duela. Egitura partitiboak horixe egiten du bakoitz -en kasuan. Asko eta bakoitza-ren arteko diferentzia hau beste batekin lotu nahi nuke. Zenbatzailearen izen osagarria isiltzeko orduan ez dute biek berdin jokatzen :

(33) a. [_ bakoitza] bere orduan etorri da

b. $\left({ }^{*}\right)$ [_ asko] berandu etorri da

(33a)n izen zenbagarri bat uler dezakegu. (33b)n ez. (33b) masa izen bezala bakarrik uler daiteke (nekez berandu etortzen diren horietakoak), berriz ere masa izenak eta zenbagarriak bereizten direlarik. Hau da, asko zenbatzaileaz osaturiko sintagma komunztaduragabeek ezin dute haien izena isildu, bakoitz -ez osaturikoek bezala. Eman dezagun, ohi denez, izenen isiltzea komunztaduraren menpeko fenomenoa dela. (33b)k erakusten du asko -ren forma mugagabea zinezko mugagabea dela. Aldiz, esan genezake bakoitz -ek singularreko komunztadura tasun bat eduki dezakeela, aukeran (Beghelli eta Stowell, 1997, antzeko proposamen baterako ingelesez). Formalki, singularra eta komunztadura eza berdinak lirateke 3. pertsonan. Bakoitz -en partitibozko formek beharrezkoa izango lukete. Komunztadura tasun hau, propietate pronominalak dituena (Chomsky,1981; Rizzi,1986) sintagma diskurtsuan ainguratzeko balio du. Badakigu predikazio kategorikoek subjektu mugatu bat behar dutela, hots diskurtsuan ongi ainguratua: komunztadura tasun pronominalak lan hori egiten du.

\subsection{ELKARKARIAK}

Asko zenbatzaileaz hornituriko sintagmek beti interpretazio plurala duten arren, elkarkariak ezin txerta daitezke komunztaduragabeko kontestuetan ${ }^{17}$.

(34) a. *Ikasle askok elkarren antz haundia du b. Ikasle askok elkarren antz haundia dute

(35) a. *Ikasle askok elkar/bata bestea iraintzen du

b. Ikasle askok elkar/bata bestea iraintzen dute

(36) a. *Ikasle askok elkarri/bata besteari loreak oparitzen dizkio

b. Ikasle askok elkarri/bata besteari loreak oparitzen dizkiote

(37) a. *Ikasle asko elkarrekin/bata bestearekin joan da eskolara

b. Ikasle asko elkarrekin/bata bestearekin joan dira eskolara

Problema elkarkariekin da, ez orohar erlazio anaforikoekin ${ }^{18}$. Hona bihurkariak :

(38) a. Irakasle askok bere burua goraipatzen du

b. Irakasle askok beren burua goraipatzen dute

Hau esplikatzen ahal da asko singularrekoa distributiboa bada. Zenbatzaile distributiboek ez dute elkarkaririk onartzen, pluraltasuna adierazi arren, bai ordea $X$ ren burua tankerako bihurkariak :

(39) a. *Ikasle bakoitzak elkar ikusi du

b. Ikasle bakoitzak bere burua goraipatu du 
Arrazoia hauxe litzateke (Heim, Lasnik eta May, 1991, 75-76.orr.) : Elkarkariek badute (elkarkari izate hutsagatik, hots, beren egitura logikoan) distributiboa den atal bat, zenbait hizkuntzatan agerikoa dena ${ }^{19}$. Zenbatzaile distributiboek plurala den multzo baten baitan operatzen dute. Distribuzio operadorearen zeregina multzo plurala banakako aletan banatzea da, eta ale bakoitzari buruz predikazio bat ahalbideratzea. Honek esan nahi du ezin dela bi aldiz distribuzioa egin. Lehenengo banaketak multzo plurala banako aletan desegin du dagoeneko, eta banako ale horietan ezin da berriro distribuziorik eragin. Ikusi dugu komunztaduragabeko asko distributiboa dela. Eman dezagun Heim, Lasnik eta May-ren elkarkarien analisi semantikoa zuzena dela : orduan bi distribuzio operadoreren aitzinean gaude, eta horietako batek ez du banaketarik egiten ahal. Goiko perpausen arazoa beraz, semantikoa da. Ez da gauza bera gertatzen pluraleko formekin: hauek, ikusi dugun bezala, ez dute nahitaez intepretazio distributiborik. Hortaz operadore distributibo bakarra elkarkariak berak ekarritakoa da.

\section{4. - Ia BANAKARIA}

Asko -ren izaera distributiboak modu sinple batean biltzen ditu singularreko formen hiru propietate desberdin: uztardurako mugak, interpretazio distributiboa, eta elkarkariekin josi ezina. Badu ordea problema bat : ezin du -na banakariarekin agertu, bestelako zenbatzaile distributiboak ez bezala ${ }^{20}$ :

(40) a. ??Ikasle askok liburu bana erosi du

b. Ikasle askok liburu bana erosi dute

(41) a. Ikasle bakoitzak liburu bana erosi du

b. Mundu guziak liburu bana erosi $\mathrm{du}^{21}$

Zergatik portaera berezi hau, zenbatzaile distributiboei buruz ? Hemen konponbide bat kirrimarratu besterik ez dugu egingo. Distribuzio orok baditu hiru atal (Heim, Lasnik eta May, 1991 ; Beghelli eta Stowell, 1997, besteak beste): (i) multzo plural bat, zeinen baitan distribuzioa egiten baita ; (ii) operadore distributibo bat (goiko bakoitz -en gisakoa); eta (iii) distribuzioa jasaten duen elementu bat : hau sintagma bat izan daiteke (euskaraz - na bezalako atzizki batez lagundua ager daiteke orduan), edo eventua adierazten duen elementua, eventu-aldagai bat ${ }^{22}$ (hortara behartuak gaude beste jasailerik ez dagoenean, 2.2. ataleko exenpluetan bezala). Eventu aldagai hau aditz izenaren bitartez edo inflexioaren bitartez adierazten $\mathrm{da}^{23}$. Kasu horretan banatua dena eventua bera da. Zuzen bagabiltza asko ren izaera distributiboa defendatzerakoan, ateratzen den ondorioa da singularreko formek ezin dutela, antza denez, eventua ez den beste jasailerik onar. Hori da funtsean-na rekin konbinatu ezina esaten ari zaiguna. Galdera, beraz, da zergatik singularreko formek behar duten eventua hartu distribuzioaren jasaile bezala. Ez dugu hemen argituko, baina honek bide ematen digu asko komunztaduragabekoaren bigarren propietate semantikoaz mintzatzeko, zeinekin, nere ustez, lotua baitago. Asko singularrekoa modu berezi batean lotzen zaio eventuari, ikusiko dugun bezala. 


\section{Asko mugagabearen interpretazio proportzionala}

Asko mugagabeak balio proportzional bat du erantsia. Ikus esate baterako perpaus hauen arteko diferentzia :

(42) a. Espainian euskaldun asko daude

b. Espainian euskaldun asko dago

Lehenbiziko perpausa egia izan daiteke edo ez, asko izatearen muga non jartzen den. Ifarraldeko ikuspegitik begiratuta, agian egia da. Bigarrena ordea faltsua da, bete betean. Espainian, nola begiratzen den ere, ez dago euskaldun askorik. (42b) perpausean dimentsio berri bat sartu dugu : proportzionalitatearena. Espainian diren lagun guziak hartuta, euskaldunak proportzio ttipi bat besterik ez dira, eta ez dago esaterik euskaldun asko dagoenik. Beste hitzetan esanik : mugagabeko formak agertzen diren perpausen egiatasuna evaluatzeko asko ren izen osagarriak denotatzen duen sailaz haraindi jo behar dugu : euskaldunen kasuan (42b)n euskaldun ez direnak ere kontutan hartuaz ${ }^{24}$.

Axolazko dimentsioa hemen proportzioa baldin bada, predikzio bat egiten dugu : proportziorik ametitzen ez duten kontestuetan mugagabeko asko-k ez luke ongi eman behar. Kontsidera ditzagun, hartara, honako perpausok :

(43) a. ??Puzzle horretan zati asko dago

b. Puzzle horretan zati zail asko dago

(43a) arrotz egiten zaigu. Puzzlea eta puzzlea osatzen duten zatien artean ez baitago proportzio bat ezartzerik. Aldiz (43b)n proportzio bat sartu dugu, zati errezaketa zailak (eman dezagun, zeru beti urdinari dagozkionak) bereiziaz. Kasu horretan, perpausa onargarria da. Ohar gaitezen pluraleko formekin ez dagoela inolako problemarik :

(44) a. Puzzle horretan zati asko daude (nolako pazientzia izan duzun!)

b. Puzzle horretan zati zail asko daude

Printzipioz, proportzionalitatearen ezaugarri horrek ez ditu besterik gabe mugagabeko formak eta pluralekoak bereizten. Pluraleko asko ere proportzionala izan daiteke (Partee, 1988) :

(45) Ikasle asko nekatuta etortzen dira eskolara

(45) bezalako perpaus batek, kontestuaren arabera, bi interpretazio izan ditzake : bata kardinala edo " ahula », zenbateko hutsaz ari dena. Bestea, berriz, multzo baten barnean hautaketa egiten duena, partitiboa, « ikasletariko asko » ri dagokiona. Irakurketa hau proportzionala da. Eta proportzioa zenbatzailearen osagarriaren (izenaren) denotazioaren barnekoa da : haren azpimultzo bat, alegia. Aldiz, mugagabekoaren proportzioa ez da izenaren baitan ezartzen. (46a) ez da (46b)ren parekoa :

(46) a. Ikasle asko etorri da gaur

b. Ikasletariko asko etorri dira gaur 
Baizik eta (47)rena :

(47) Gaur etorri direnen artean asko ikasleak dira

Irakurketa honetan, eventua bera zenbatzailearen barruti edo errestrikzioan sartzen da.

\section{Ondorioak}

Asko komunztaduragabearen eta komunztaduradunaren arteko diferentzia semantikoak aztertu nahi izan ditugu hemen, kontestu sintaktiko desberdinetan sortzen diren portaera berezituei begiratuaz. Erakutsi dugu komunztaduragabeko formak bi propietate nagusi dituztela : distributiboak eta proportzionalak dira. Komunztaduragabeko formen proportzionaltasuna eventuaren eduki deskriptiboa baliatuz osatzen da. Komunztaduradun formak ere proportzionalak izan daitezke, baina holakoetan erlazio proportzionala ez da eventuaren deskripzioan bilatzen, baizik eta zenbatzailearen izenezko osagarrian.

\section{Bibliografia}

BEGHELLI, F. eta T. STowell (1997) « Distributivity and negation : the syntax of each and every » Szabolcsi, A. (arg.), 71-108.

Coyos, J.-B. (1999) Le parler basque souletin des Arbailles : Une approche de l'ergativité, LHHarmattan, Paris.

EUSKALTZAINDLA (1985) Euskal Gramatika Lehen Urratsak I, Iruñea.

EuskaltZandia (1993) Euskal Gramatika laburra : Perpaus Bakuna, Bilbo.

HEIM, I., H. LASNIK eta R. MAY (1991) « Reciprocity and Plurality » Linguistic Inquiry, 22: 1, 63-101. orr. IRIGOIEN, A. (1985) « Euskarazko izen sintagma mugatzailerik gabekoez " Euskera XXX, 129-139.

KosLICKI, K. (1999) «The Semantics of Mass Predicates » Noûs $33: 1,46-91$.

KURODA, Y. (1972) «The categorical and the thetic judgement » Foundations of Language 9, 153-185.

LAFrTE, P. (1977) Grammaire basque, Elkar, Donostia.

LINK, G. (1983) «The logical analysis of plurals and mass terms : a lattice-theoretical approach » R. Bauerle

(arg.) Meaning, Use and Interpretation of Language, Walter de Gruyter, 302-323.

MISARK, GARY (1977) Existential sentences in English, doktoradutza tesia, MIT.

Mrtxelena, K. (1985) Fonética histórica vasca, Donostia.

PARTEE, B. (1988) «Many Quantifiers » Proceedings of the Fifth Eastern States Conference on Linguistics (ESCOL 88), Ohio State University, 383-402.orr.

PELLETIER, F.J, eta SCHUBerT, L. (1989) «Mass Expressions » D. Gabbay eta F. Guenthner (arg.) Handbook of Philosophical Logic, IV, 327-407.

REINHART, T. (1983) Anaphora and semantic interpretation, Croom Helm, London.

SzABolcSI, A. (arg.) (1997) Ways of Scope Taking, Kluwer Academic Press.

SzABolCSI, A. (1997) « Background Notions in Lattice Theory and Generalized Quantifiers » Szabolcsi (arg.)

ROTAETXE, K. (1979) « Numeral eta aditzen arteko konkordantziaz » FLV 32, 259-267.

TXILlaRdegi (1977) Oinarri bila, Donostia

TxILLARDEGI (1977) « L'emploi de l'indéfini en Souletin », ELV 29

TxILlArdegr (1978) Euskal Gramatika, Ediciones Vascas, Donostia.

VILLASANTE, L. (1983) Estudios de sintaxis vasca, Editorial Franciscana Aranzazu, Oñate.

ZrRBi-HerTZ, A. (1996) L'Anaphore et les Pronoms, Presses Universitairesdu Septentrion. 
1. Zenbatzaile " ahulak » bezala ezagutzen direnak : asko, gutxi, hainbat, franko, zenbait, ugari, gehiago/gutxiago (Milsark, 1977).

2. Apartean gelditzen da Villasante (1983), zeinentzat guti, hainbat, zenbait eta franko mugagabean bakarrik agertzen diren. Aski da begiratu bat OEHari ikusteko ez dela hala.

3. Lanaren mugak garbi azal ditzagun: batetik, ez ditugu gainerako zenbatzaileak tratatuko (lan hori bidean da). Bestetik, datuak Irun-Hondarribi aldekoak dira, anitz beraz, ez dugu aintzat hartuko. Anitz ek ikerketa berezitua behar du, seguru aski (eskerrak Beñat Oihartzabali, asko eta anitz -en arteko diferentzia batzuk seinalatzeagatik, komunztaduraren inguruan). Kanpoan gelditzen da baita ere zenbatzaile kardinalekin hizkera batzuetan gertatzen bide den antzeko fenomenoa (Txillardegi,79 ;Euskal Gramatika Laburra: Perpaus Bakuna). Hemen tratatzen dugun fenomenoaren distribuzio dialektala ere, eginkizun gelditzen da. Ikus baitaere 8. Azpioharra. Nere eskerrona agertu nahi diet Maite Berruet eta Mayi Izari, nere galderak erantzuteagatik eta datuak eztabaidatzeagatik

4. Txillardegik (1977) honako exenpluak ekartzen ditu (hau Santakruz bertsolariarena, 78.orr) : « zenbait predikadorek/sermoia asten du/eta atentziyua askok paratzen du ». Baina nola jakin hemen multzoaz mintzo garen ala ez?

5. Hona hitzak: « Zenbakariak plurala baitira erdaraz, kalko-bidez sartu zaizkigu gero eta gehiago pluralezko komunztadurak » (37.orr.). Araua emateko orduan baina, egungo egoera kutsatuari men egin behar zaiola dio: « ... honen zabalkundea dela medio, onartu beharrekna ». Txillardegi/Larresororen bidea hartu zuen baita ere Garmendiak (Euskera, 1968, XIII, 287-290).

6. Txillardegik Etxepareren bertso batzuk dakarzki bere hipotesiaren berme. Hona hemen :

« anhitz gizon ari bada andrez gaizki erraiten

arhizki eta desoneski baitituzte aipatzen »

Bere hitzak : « anhitz gizon horrek osatzen duen multzoa lehenengo aldiz ajpatzerakoan (oraindik ere, beraz, gizon-multzoa ez-ezaguna denean), « bada » irakurtzen dugu. Multzoaren berri dugunean, berriz,... » baitituzte » plurala irakurtzen dugu ». Esplikazio hau ez da berez uztartzen hipotesiarekin: ez dirudi nahitaez Etxepareren azken bertsoa gaizki mintzo direnen banakako berri ematen duenik. Edozein kasutan, multzo bat aipatzeak ez ditu multzo horretako elementuak ezagun egiten: gaizki mintzo direnez ari da, nor ere baitira. Honelako exenpluek bestelako esplikazioa dute uztardura izeneko fenomeno sintaktikoaren barnean. Ikus 2.1. atala.

7. Ikus bereziki Irigoien (1985,1987). Baita Rotaetxe (1979).

8. Bere hitzetan: « ...mugagabeak singularra behar du aditzean beti. Nahiz kopuruari dagokionez, bi, hiru, mila, asko ala majina bat izan. Zuberoan erregela hau osoki betetzen da ; bestetan, erdalkeria aurreratu ala, ahuldu egin da erregela » (61. orr.). Txillardegik Etxahunen azterketa bat aurkezten du horren erakusle (FLV, 25, I-IV, 1977 ; 29-55). Baina Etxahunengan bertan ez da zaila kontrako adibideak aurkitzea (ikus, esaterako, Haritschelarren edizioan, « Ahaide delezius huntan » en lehen lerroa), eta komunztaduraren joan-etorriko portaera hori asko, zenbait eta antzekoen eremura zabaitzen da Etxahunengan. Baita Tartasengan ere, bide batez ( « Ontsa hiltzeko bidia » ren Eguzkitzaren edizioan, 64.orrialdea hirugarren lerroa, edo 65.ean, beste hainbatekin batera). Gèze-k (Eléments de Grammaire basque, Dialecte souletin, 1873) ere ez du aipatzen komunztadura singularrekoa behar duenik. Darrigolek (1827) beharrezkoa jotzen du numeroko komunztadura (Rotaetxe, 1979) pluraltasuna adierazten duten sintagma guziekin.

9. Ikus 233-234.orr. Hona Coyos-en beraren egoeraren laburpena (234.orr.) : « ... on pourrait observer que l'indication du nombre relève plutôt du marquage accusatif puisque l'accord se fait plus aisément avec un nominal à absolutif suffixixé déterminant un verbe à auxiliaire izan ... qu'avec un nominal à absolutiff suffixé déterminant un verbe à auxiliaire edun... et obligatoirement avec le nominal à suffixe ergatif... On pourrait dire au contraire que le nominal avec l'ergatif se differencie des deux autres : l'accord pluriel est obligatoire avec un quantificateur [hanitx, kasu honetan] et pas avec les nominaux à l'absolutif. Ceci est un trait d'ergativité » Sistema beraz aski konplexua da, eta ezin jar daiteke zuberera Txillardegiren komunztaduraren hipotesiaren oinarritako. Zubereraren sistema, beste aldetik, artikulu honetan deskribatuko dugunaren diferentea da. Iduri du sistema horretako ezaugarri batzuk ekialdeko beste hizkeratan ere agertzen direla. Sistema horiek beraz, ez dute zertan hemen deskribatzen dena bezalakoa izan behar, eta ikerkizun uzten ditugu.

\section{EGLU I-i jarraiki, beste honenbeste egiten dute Odriozola eta Zabalak (1992, 73.orr.)}

11. Hemen literatura zabal bat daukan masa kontzeptu linguistikoaz ari naiz (ikus Schubert eta Pelletier, 1989 ; Koslicki, 1999). Ez agian, EGLU I eko « masaz ». Normalki komatxoak ez dira inozenteak izaten. Esan behar da Euskaltzaindiaren Euskal Gramatika : Perpaus Bakuna-k (1993) ez diola ikuspegi honi segit- 
zen. Masa bezala hartzen den harriak singularreko komunztadura hartzen du. Banako edo zenbagarri gisa hartzen denak singularrekoa nahiz pluralekoa (106.orr.) Berehala sortzen den galdera da diferentziarik ote dagoen azken kasuan singularreko eta pluraleko formen artean. Horixe (aldez behintzat) argitzea du artikulu honek xede.

12. Homogenoak diren predikatuak kumulatiboak eta banagarriak (divisive) dira (Link, 1983).

13. (10a) perpausa ona da baldin eta « ardo klaseak » zenbatzen baditugu, baina jakina, hori ez da masairakurketa. Beste horrenbeste hainbat -i dagokionean.

14. Guzti, dena, batzuk, Art+oro bezalakoak ez dira halabeharrez banatzaile, bakoitz -en edo singularreko asko -ren gisan (ikus hurrengo atalak), eta ez dute halakoek uztardurarako erakusten duten murriztapenik erakusten. Bakoitz -en gisako zenbatzaileen eta asko -ren gisakoen komunztadura arauak ez datoz agian guziz bat. Ikus 2.3. atala.

15. Gauza bera gertatzen da beste zenbatzaileekin ere. Singularreko komunztaduradun formak bakarrik interpretazio distributiboa onartzen dute. Adibidez hainbat-ekin :

(i) a. Hain bat ikaslek harritzarra mugitu zuten (kolektiboa/distributiboa)

b. Hainbat ikaslek harritzarra mugitu zuen (distributiboa)

16. Interesgarria da ikustea soziatibo bat sartzen badugu perpausa ona dela :

(i) Ikasle ohi asko bere gaztaroko neskalagunarekin topatu zen festa hartan

Kasu honetan ikasle asko - $\mathrm{k}$ adierazten duen multzoa ez da nahitaez kolektibo edo multzo gisa ulertu behar, eta perpausak badu interpretazio distributibo posible bat.

17. Literatura zaharrak salbuespen bakan batzuk ematen ditu zenbatasunezko aitzindariekin, baina salbuespen gehienak inpertsonalekin gertatzen dira (OEH, elkar sarrera) :

(i) Maitatzeko elkar ezagutu behar da (Jautarkol)

(ii) Elkhar behar da lagundu (Goyetche)

Inpertsonalek subjektua ezabatua dute, eta pluraleko zentzua dauka. Ez dut zer esanik.

18. Ikus bidenabar, $X$-ren burua kasuek oso nekeza egiten dutela bai masa interpretazioaren hipotesia (EGLU I) eta baita multzo interpretazioarena ere (Txillardegi, 1978), hemen banakoen buruez ari baikara.

19. Ingelesez, forma konplexuak dira : each other. Lehen atala, each « bakoitz ", zenbatzaile distributiboa da. Bigarrena, haiek « the reciprocator» deitzen dutena, da banaketa horren aldagaia beste zerbait edo norbaitekin harremanetan jartzen duena, ingelesez other « beste ». Interesgarria da Uhlenbeck-ek (1928, 168.orr) -eta Mitxelenak (1985, 69.orr.), hari jarraiki- jatorri konplexua ikusten diotela euskarazko elkar elkarkariari: *hark har (izañoak hemen alegiazko forma etimologikoa markatzen du).

20. Beste horrenbeste gertatzen da singularreko formez horniturik ager daitezkeen beste zenbatzaile batzuekin (gutxi eta hainbat adibidetako ematen ditugu) :

(i) a. *ikasle gutxik erosi du liburu bana

b. Ikasle gutxik erosi dute liburu bana

(ii) a. *Hainbat ikaslek liburu bana erosi du

b. Hainbat ikaslek liburu bana erosi dute

21. Mundu guzia ere distributiboa da

(i) Mundu guziak harritzarra altxatu du (banaka izan behar du)

22. Eventu aldagaiaren ideia Davidson-engandik heldu da (1965). Davidson-entzat edozein esaldi jokatu eventu baten gaineko kuantifikazioa da. (i)-i dagokion forma logikoa ez da, Davidsonen ustetan (iia) (logikan eskuarki ematen dena), baizik eta (iib) :

(i) Xabier goiz azaldu da

(ii) a. Azaldu (goiz (Xabier)

b. E(e) [Xabier, etorri, e]

(iib) honela irakurri behar da: « Bada eventu bat Xabier eta etorrera bat biltzen dituena ». Honen itxura espekulatiboa gora-behera, eventu semantikak garrantzi handia hartu du hizkuntza naturalen deskripzioan azken hogei urtetan, oso emaitza interesgarriekin (erreferentzia honez gero klasiko batzuk: Higginbotham, 1985,1987;Pàrsons, 1990).

23. Honen inguruan eztabaida dago. Lehenaren alde: Benedicto (1996), Baker eta Iravis (1997) eta Etxepare eta Grohmann (2000). Bigarrenaren alde, besteak beste: Higginbotham (1984). Kztabaida funtsean aditz igoerak ondorio semantikorik duen edo ez da.

24. Honek esan nahi du asko mugagagabea ez dela monotonikoa, ez baitu « lekuko minimorik» (« witness set », Szabolcsi, 1997). Lekuko minimoak zenbatzaile baten eremuaren (domain) lekukotzat har dai- 
tezkeen gutxieneko multzoak dira. Esate baterako « bi gizon » bezalako zenbatzaile sintagma batean, lekuko minimoa bi gizon eta deus gehiagorik biltzen ez duen multzoa da. Honelako zenbatzaileak monotonikoak dira. « Monotonikoa » esan nahi du inferentzia kate bat ahalbideratzen duela multzo eta azpi multzoen artean. Har dezagun " bi gizon altu ". Honek goranzko inferentziak baimentzen ditu: bi gizon altu etorri badira orduan bi gizon etorri dira eta orduan bi bizidun, e.a., beraz monotonikoa da gorantz. Monotonikoak ez direnek ez dute honelako inferentzia katerik baimentzen. Esate baterako, « gizon altu gehienak » ez du goranzko (ez beheranzko) inferentziarik baimentzen : gizon altu gehienak etorri badira orduan ez dira nahitaez gizon gehienak etorri, e.a. Asko mugagabeak ez du honelako inferentziarik baimentzen eztaere: euskaldun hankamotz asko badago euskal herrian ez da halabeharrez egia euskaldun asko dagoenik, ezta hankamotz asko dagoenik ere. Proportzio bat ezartzen duten zenbatzaile guztiak ez -monotonikoak dira. 